\title{
A Camelot-projekt - az Egyesült Államok Hadseregének társadalomtudományi kutatási projektje ${ }^{2}$
}

\author{
Project Camelot - a U.S. Army Social Science \\ Research Project
}

\begin{abstract}
Absztrakt
A Camelot-projekt egy ambiciózus társadalomtudományi projekt volt, amely 1964 végén lépett életbe. A projekt célja azon intézkedések azonositása volt, amelyeket az amerikai kormánynak meg kellett tennie ahhoz, hogy megakadályozza a háborúk kialakulását a háború okainak felmérése által. A projekt alkalmazása és annak végsö lezárása közötti időszak érdekes kérdéseket vet fel az amerikai kormány, a haderő és a társadalomtudományok kapcsolatáról.
\end{abstract}

Kulcsszavak: antropológia, Camelot-projekt, amerikai haderő

\section{Abstract}

Project Camelot was an ambitious social science project that came into existence in late 1964. The goal of the project was to assess the causes of war and to identify the actions a government could take to prevent such wars. The period between the introduction of Project Camelot and its ultimate demise raises interesting questions about the relationship between government, the military, and social sciences.

Keywords: anthropology, Project Camelot, U.S. military

Nemzeti Közszolgálati Egyetem, Hadtudományi és Honvédtisztképző Kar, tanársegéd - University of Public Service Faculty of Military Science and Officer Training, Assistant Lecturer, e-mail: sztankai.krisztian@uni-nke.hu, ORCID: http://orcid. org/0000-0003-3857-3296

2 Az Innovációs és Technológiai Minisztérium ÚNKP-19-3-III-NKE-13 kódszámú Új Nemzeti Kiválóság Programjának szakmai támogatásával készült. 


\section{Bevezetés}

Ahhoz, hogy jobban megértsük a Camelot-projekt működését és célját, meg kell vizsgálnunk a Special Operations Research Office (SORO) szervezetét, amely a Camelotprojekt felelőse és kivitelezője volt. A Különleges Müveletek Kutatási Hivatalát 1956-ban hozták létre, azzal a céllal, hogy különféle témákban jelentéseket készítsen az Egyesült Államok hadseregének. A nyolc múködési éve alatt a SORO megközelítőleg 50 könyv hosszúságú tanulmányt készített több európai, ázsiai, közel-keleti, afrikai és latin-amerikai országokról, amelynek alapfilozófiája az operatív kutatás és rendszerelemzés, vagyis az ORSA (Operations Research and Systems Analysis) volt. ${ }^{3}$

\section{Operations Research and Systems Analysis - ORSA}

Az ORSA egy olyan tudományfilozófia, amely a II. világháború időszakában jött létre. Az operatív kutatás, a legtöbb tudománytól eltérően képes a körülmények és események jól definiált kombinációjára rámutatni. Miután Hitler hatalomra került Németországban, Anglia megfelelő védelemre törekedett a lehetséges légitámadásokkal szemben, amelynek eredményeként 1937 végére kidolgozták a hatékony védelem kulcsfontosságú elemeit: a radart és a Hurricane vadászgépet. Azonban ezeket az eszközöket nem lehetett a hatékony rendszerbe beilleszteni és az improvizációra hagyni, amint azt 1938 júliusában egy légi gyakorlat kiábrándító eredményei is megmutattak. Ez az új típusú kutatás, amelyet a Brit Királyi Légierő tisztjeivel szoros együttműködésben végeztek közvetlenül az angliai légvédelmi rendszer lényeges fejlesztéseiben jelentek meg, amely az 1940-es augusztus és szeptember közötti Nagy-Britanniában folytatott csata során megkapta, és ki is állta a próbát.

A tudósok és a múveleti erők közötti partnerség sikere ösztönözte az operatív kutatás terjesztését más brit parancsnokságokhoz és szervezetekhez. Amikor az Egyesült Államok belépett a háborúba, ezt a brit példát az amerikai katonai vezetők is követték, aminek eredményeként 1942 végére amerikai tudóscsoportok alkalmazni kezdték az Egyesült Államok Haditengerészeténél és a Hadsereg Légierejénél. A nevet azonban amerikanizálták és operations researchnek, azaz operatív kutatásnak nevezték el. A háború végére Anglia, Kanada és az Egyesült Államok már 700 tudóst foglalkoztatott az operatív kutatásban. ${ }^{4}$

Miközben a hadsereg vizsgálta az ORSA követelményeit, az egész hadsereg elemző szervezete mind a hagyományos múveleti kutatási módszereket, mind a rendszerek új módszereit és költséghatékonysági elemzését alkalmazták a fegyverrendszerek fejlesztésénél, a taktikai és stratégiai doktrína kialakításában meglévő problémákra. Valójában a hadsereg szervezeteinek száma és létszáma - szerződéses és házon belüli-, amelyek ORSA-módszereket alkalmaznak a jelenlegi hadsereg problémáinak megoldására és a jövő tervezésére, a McNamara-évek során jelentősen megnőtt.

David H. Price: Cold War Anthropology: The CIA, the Pentagon, and the Growth of Dual Use Anthropology. Duke University Press Books, 2016. 211.

4 Hugh J. Miser: Operations Research and Systems Analysis. Austria, International Institute for Applied Systems Analysis, 1980. 2-3. 
A háború végére, Anglia, Kanada és az Egyesült Államok 700 tudóst foglalkoztatott ezekben a kifejezésekben lazán leírt munkában. A programban részt vevő tudósok munkájának egy részét csupán a müszaki háttérben hasznosították. Fontos újdonság volt, hogy megvizsgálták és kiértékelték a taktikai műveletek eredményeit, kidolgozták a harcászati újításokat, megjósolták azok következményeit, és az innovációkat ténylegesen alkalmazták, összehasonlítva a várt eredményeket a ténylegesen elért eredményekkel. Ez a tudás gyakran alapul szolgált a taktikai tervezéshez, sőt a háború későbbi szakaszaiban is fontos tudást nyújtott a stratégiai döntésekhez. ${ }^{5}$

A SORO megjelenése előtt fontos megjegyezni, hogy az 1960-as és az 1970-es évek eleje viharos időszak volt a világtörténelemben. A magukra ébredt/felkelő politikai mozgalmak, valamint a mély gazdasági és társadalmi változások a világ sok régióját érintették, köztük az Egyesült Ảllamokat is. A technológia gyors fejlődése és a változó nemzetközi politika, különösen a vietnámi kommunista felkelés jelentős változásokat kényszerített az amerikai hadsereg fegyverzetében, szervezetében és doktrínájában. Az ilyen alapvető és gyors változásokkal nem lehetett volna megbirkózni a múveleti kutatások és rendszerelemzési (ORSA-) technikák nélkül, amelyek nagyban hozzájárultak a hadsereg hatékony döntéshozatalához az érintett időszakban.

\section{A Különleges Müveleti Kutató Iroda}

A Különleges Múveleti Kutató Irodát a washingtoni American Universityn hozták létre, hogy támogassák a hadsereg felkelés elleni múveletek, nem szokványos hadviselés és pszichológiai múveletekkel ${ }^{6}$ kapcsolatos kutatásait. A SORO kutatásai magukban foglalták az adott terület politikai, gazdasági, társadalmi és kulturális vizsgálatait, valamint az adott országban meglévő konfliktusok és felkelések okait és jellegét, továbbá azok leküzdésének taktikáit. A vizsgálataikban hangsúlyozottan szerepelt a külföldi lakosság pszichológiai sebezhetősége és annak kiaknázásának lehetőségei, valamint az érintett országok számára egy esetleges katonai segítségnyújtás kivitelezhetősége. ${ }^{7}$

1962 márciusától kibővítették a SORO állománytábláját a szokásos felügyeleti, adminisztratív és támogató elemekkel, valamint két technikai részleggel (Kutatási Osztály - Research Division és Külföldi Tanulmányok Osztály - Foreign Area Studies Division), amelyek feladatát külön szerződés szabályozta. A Kutatási Osztályt egy igazgatóval, két ágazatvezetővel és hat interdiszciplináris kutatócsoporttal hozták létre. A témák széles körüek voltak, az osztály többek között a pszichológiai műveletekre és a gerilla-/felkelők elleni harcokra vonatkozó kutatások elvégzéséért volt felelős. A Kutatási Osztály tevékenységét az Amerikai Hadsereg kutatási és fejlesztési vezetője felügyelte. A Külföldi Tanulmányok Osztályát egy osztályvezetővel, két helyettessel és négy interdiszciplináris kutatócsoporttal, több történésszel és geográfusokkal, valamint egy szerkesztővel együtt szervezték meg, és országos és regionális tanulmányok készítéséért volt felelős az osztály. Az elkészített anyagok érintették

\footnotetext{
Miser (1980) i. m. 2-3.

Insurgency/counterinsurgency, unconventional warfare, psychological operations.

Charles R. Shrader: History of Operations Research in the United States Army, Volume II: 1961-1973. Washington, D. C. 2006. 199.
} 
a politikai, gazdasági, szociológiai és katonai témákat. A Külföldi Tanulmányok Osztály tevékenységét a pszichológiai hadviselés vezetője (később a különleges műveletek vezetője) felügyelte. ${ }^{8}$

A SORO küldetését 1966 júliusában átszervezték, és a nevet is megváltoztatták American University Center for Research in Social Systemsre (CRESS), amely két alkotóelemmel rendelkező osztályból tevődött össze; Social Science Research Institute - Társadalomtudományi Kutatóintézet (SSRI), valamint Counterinsurgency Information Analysis Center - Felkelők Elleni Műveletek Információs Elemző Központ (CINFAC). A Társadalomtudományi Kutatóintézet célja a „speciális szakmai tehetségek bevonása volt a konkrét társadalomtudományi kutatásokba, fejlesztésekbe, tanulmányok elkészítésébe. Az SSRI társadalomtudományi kutatásokat végzett, hogy támogassa az Egyesült Államok Hadseregének katonai múveleteit a nem szokásos hadviselés, a pszichológiai műveletek, a katonai segítségnyújtási programok, az ellensúlyok, valamint az idegen kultúrák terén." ${ }^{\prime \prime}$

A CINFAC feladata volt olyan rendszer létrehozása, amellyel támogatni tudta az Egyesült Államok Hadseregének (Army) és más Védelmi Minisztériumi (Department of Defense, DOD) szervezetek műveleteit azáltal, hogy összegyüjtötte, tárolta, visszakereste és elemezte a világ népeire és kultúráira vonatkozó információkat. A SORO egyik kutatásával kapcsolatban 1965-ben viták merültek fel, amely egy Chilével foglalkozó tanulmány kapcsán került a figyelem középpontjába, amely egy nagyobb SORO-kutatási projekt a Camelot-projekt része volt, és amely a fejletlen nemzetek forradalmának és felkeléseinek okait és a „politikai instabilitás kezelésének módszereit" vizsgálta. A Camelot-projekt vitája eredményezte a SORO-szervezet átnevezését és született meg a CRESS 1966-ban. A CRESS az American University-vel folytatott katonai szerződések alapján 1969-ig folytatta müködését. A CRESS szerződése a kutatószervezetek vietnámi szerepe elleni polgári tiltakozások után megszűnt, amelyben kimutatta, hogy milyen formában próbáltak befolyást gyakorolni a vietnámi kormány nemzeti ügyeibe. A CRESS-t később az American Institutes for Research szervezet vette át, ami egy független, nonprofit kutatási szervezet, amelyet 1946-ban hoztak létre, és a mai napig 1100 fö alkalmazottat foglalkoztat világszerte. A szervezetnek irodái vannak Pittsburghben, Washington, D. C.-ben, Palo Altóban és Bangkokban. ${ }^{10}$

\section{A Camelot-projekt}

A Project Camelot gyökerei a II. világháborúig nyúlnak vissza, ahol a pszichológusok már jelentős és növekvő támogatókkal rendelkeztek magas szintű politikai döntéshozók körében, akik nagylelkű pénzügyi támogatással és gazdag elméleti, módszertani és szervezeti tapasztalattal rendelkeztek. A Il. világháborúban a katonapszichológusok vizsgálták az ellenség mentális készségeit, terveztek több lélektani müveletet. Az 1945 utáni években a pszichológia gyorsan haladt a II. világháború tapasztalatai által felvázolt 
úton. A koreai háború és a hidegháború időszakában ${ }^{11}$ a pszichológia fenntartotta lendületét, és megalapozta jövőjét a haderőben. Ezen időszakban a pszichológia szakértői előmozdították a nemzetbiztonság tudományos célkitűzéseit és egyedi elemzéseket dolgoztak ki a harmadik világ feltörekvő államainak fejlődéséről és forradalmáról. Ezeken a területeken a szakértők gondoskodtak az elméleti és kutatási tevékenységek gyakorlati, főképp katonai hasznosságának maximalizálásáról. A világháborúban és az azt követő időszakban szerzett tapasztalataik miatt a viselkedésszakértőket szívesen alkalmazták az egyes katonai ügynökségekben. A Camelot-projekt és annak következményei bemutatják, hogy a tapasztalt pszichológiai szakértők milyen messzire jutottak el a II. világháború kialakulása óta. ${ }^{12}$

A Camelot tervezése 1964-ben kezdődött a Védelmi Tudományos Tanács (Defense Science Board, DSB) jelentése alapján, amely egy hatalmas katonai tudományos tanácsadó csoport. A DSB jelentése számos hiányosságot tárt fel a Védelmi Minisztérium (DOD) viselkedéstudományi programjaiban, különös tekintettel a világ számos apró konfliktusaira és forradalmi mozgalmaik tanulmányozására. Később a hadsereg elindította „A társadalmi változások és a belső háború potenciálja előrejelzésének és befolyásolásának módszerei" nevű nagyprojektet, amely Camelot-projekt néven vált hírhedtté. ${ }^{13}$

A Védelmi Tudományos Tanács jelentését az Army Office of Research and Development - Amerikai Hadsereg Kutatási és Fejlesztési Irodájának tervezői által megfogalmazott jelentés is elősegítette, amelyet 1963-ban fogalmaztak meg. Ebben a jelentésben aggodalmukat fejezték ki a szovjetek által támogatott „nemzeti felszabadítási háborúk" miatt. Ezeket a háborúkat a szovjetek olyan országokban támogatták, mint Kuba, Jemen és Belga Kongó. A szakértők már 1945 óta kommunikálták azt a tényt, hogy a viselkedéstudomány igen fontos tudomány a szovjetek legyőzésére, talán a legfontosabb hozzájárulása a kommunizmus megállításához. Céljuk nem volt kevesebb mint a III. világháború társadalmi és pszichológiai kihívásainak előrejelzése és ellenőrzése. A projekt kitalálói szerint: „[A] CAMELOT-projekt egy olyan tanulmány, amelynek célja egy általános társadalmi rendszermodell megvalósíthatóságának meghatározása, amely lehetővé tenné a társadalmi fejlődés politikailag jelentős aspektusainak előrejelzését és befolyásolását a világ fejlődő országaiban."14

A Camelot-projekt céljait az Egyesült Államok Külügyi Bizottságának Nemzetközi Szervezetek és Mozgalmak Albizottsága az alábbi módon fogalmazta meg:

"Az American Universityn ${ }^{15}$ müködő SORO a hadsereg számára előkészítette a Camelot projektet, melynek célja számos különféle kutatási probléma integrálása egyetlen operatív célkitüzés megvalósítása érdekében, a fejlődő társadalom általános

11 A korszak politikai hátterének és fegyveres konfliktusainak kiváló összefoglalását adja: Kaló József: A mai világrend kialakulása. A hidegháború és az 1945 utáni helyi háborúk. In Hausner Gábor (szerk.): Honvédelmi alapismeretek. Budapest, Nemzeti Közszolgálati Egyetem, 2019. 67-100. 34.

12 Project Camelot and Its Aftermath. In Ellen Herman: The Romance of American Psychology. Berkeley, University of California Press, 1995. 153-174

13 Mark Solovey: Project Camelot. In Encyclopedia of Critical Psychology. 2012.

14 Irving Louis Horowitz: The Rise and Fall of Project Camelot: Studies in the Relationship between Social Science and Practical Politics. Revised edition, The MIT Press, 1967. 47.

15 American University: Az American Universityt John Fletcher Hurst, metodista püspök alapította, aki egy olyan egyetem létrehozásáról álmodott, ahol a jövő köztisztviselőit képzik. Az 1893-as kongresszus által létrehozott és támogatott egyetem egy diákközpontú kutatóintézet, amely Washington, D. C.-ben található: Who We Are. American University. 
modelljének kidolgozása révén. Ennek a projektnek az a szándéka, hogy jobban megértse a társadalmi változás folyamatainak működését a fejlődő országokban. A SORO vizsgálta a társadalmi bomláshoz vezető okokat, valamint a kommunista megjelenése és az esetleges hatalomra jutásának lehetőségeit."16

A Camelot-projekt szándéka tehát egy általános rendszermegközelítés tesztelése lett volna az instabilitás elörejelzésére és befolyásolására több latin-amerikai országban. A Camelot azonban soha nem lépte át a tervezési szakaszt, mivel 1965 májusában - kevesebb mint egy évvel az után, hogy a chilei sajtó felháborodott a kiszivárgott tervek miatt - elindított az Egyesült Államok kormányán belül is olyan reakciót, amely a projekt visszavonásához vezetett. A projekt ott bukott el, hogy egy chilei profeszszor együttmüködésének részleteit célzó ajánlatot kiszivárogtattak. A nem várt nagy társadalmi felháborodás miatt a kongresszus képviselői attól tartottak, hogy az ilyen „trükkös kutatások" veszélyeztethetik a fontos külföldi szövetségeket. ${ }^{17}$

Fidel Castro, Che Guevara és Ho Si Minh vezetésével a nagy forradalmak bizonyították, hogy a Camelot-projektben dolgozó társadalomtudósok alkalmazása nélkülözhetetlen ahhoz, hogy megértsék a forradalmi mozgalmak és felkelések forrásait Latin-Amerikában, és különböző stratégiákat dolgozzanak ki annak elemzésére. A SORO úgy hivatkozott ezekre a kutatásokra, mint a „felkelések megelőzésére” szolgáló kutatásokra. Kezdetben hat országot választottak a tanulmányhoz, az első Chile volt.. ${ }^{18}$

1965 áprilisában Hugo Nutini, a chilei születésű pittsburghi egyetem antropológusa Chilébe utazott, hogy tudósokat toborozzon egy viselkedéstudományi kutatási projekthez, amely a forradalmi folyamatot és a felkelések elleni intézkedéseket vizsgálná, és a Camelot-projekt nevet viseli. Amikor a chilei tudósok rájöttek, hogy valójában az amerikai hadsereg finanszírozza a kutatást, kérdőre vonták Nutinit, aki tagadta e tényt. Annyira elmérgesedett a helyzet a chilei társadalomtudósok, a chilei kormány és Nutini között, hogy mind az akadémia, de még a chilei kormány is megtiltotta visszatérését hazájába. Időközben a Camelot-projekt kritikája messze meghaladta a chilei határokat. A hidegháború kapcsán az Egyesült Államokkal ellenséges kapcsolatokkal rendelkező országok, Kubától a Szovjetunióig elítélték ezt a projektet. A negatív nemzetközi visszhang az amerikai kormány számára is problémákat okozott. Robert McNamara amerikai védelmi miniszter 1965. július 8-án visszavonta a projektet, hogy csökkentse a program által okozott politikai károkat, de a katonaság továbbra is finanszírozta ezeket a tanulmányokat minősített kutatás égisze alatt. A nyilvános politikai visszalépés a projekttől azonban további vitákat váltott ki a társadalomtudósok, politikusok és újságírók körében. ${ }^{19}$

Amikor a Camelot-projekt valódi természete kiderült, kénytelen volt korlátozni annak nyilvános tevékenységét, így az amerikai hadsereg titokban tovább finanszírozta a bizalmas kutatásokat, amitől azt várták, hogy megismerhetik a vizsgált országban zajló, a múlt konfliktusainak háttereit, magyarázatot kaphatnak a forradalmi folyamatok általánosságairól, és prediktív modellt állíthatnak fel a konfliktusok elörejelzésére. Egy olyan elemző módszert szerettek volna létrehozni, amely nagy valószínűséggel

\footnotetext{
Keil Eggers: Project Camelot: A Legacy of Imperial Geostrategy. 2014.

Lois Reivich: The Rise and Fall of Project Camelot. Nacla, 2007.

Hugh Gusterson: Project Minerva and the Militarization of Anthropology. Questia.

Solovey (2012) i. m.
} 
megjósolja egy adott régió vagy ország belső konfliktusainak mértékét, kialakulását. Azt várták, hogy az ilyen ismeretek elősegítik a katonai vezetők számára a társadalmi változások előrejelzését, és lehetővé teszi számukra a hatékony beavatkozás megtervezését az USA hidegháborús politikai céljainak és katonai szükségleteinek szempontjából. Walt W. Rostow gazdaságtörténész szerint, aki Kennedy és Johnson elnök nemzetbiztonsági tanácsadója volt, erőteljes általánosításokat biztosított volna az Egyesült Államok számára az úgynevezett tradicionális társadalmakról. A Camelotprojekt bezárása előtt azzal a pozitív céllal hitegette a támogatóit, hogy jelentős tudományos haladást ér el, amely elősegítheti az amerikai külpolitikai célokat, kielégítheti a katonaság változó tudásigényét, miközben egyidejüleg segít a kommunista előretörés megakadályozásában. Ambiciózus céljai miatt a Camelot nagy lehetőség volt több pszichológus körében, akik úgy gondolták, hogy a kormánnyal és a katonasággal együttműködve hozzájárulhatnak a demokrácia és a szabadság kialakításához. ${ }^{20}$

A külföldi országok legnagyobb aggodalma az volt, hogy a Camelot-projekt feltárta az USA külpolitikájának azon szándékát, hogy érdekeinek megfelelően beavatkozzon a világ bármely országának belső konfliktusaiba. A kémkedés egy rejtett formájaként hivatkoztak a projektre, amelyben tudományos kutatás révén sértették meg a vizsgált országok szuverenitását. ${ }^{21}$

\section{Minerva, a 21. század Camelot-projektje}

Az al-Káida 2001. szeptember 11-ei támadása nagyban megváltoztatta az amerikai nemzetbiztonsági szervezetek kutató-elemző struktúráját, és megpróbáltak pontosabb előre jelző rendszert kiépíteni, amelyhez nélkülözhetetlenné vált a társadalomtudósok létszámának növelése és a szorosabb együttmüködés kialakítása. A Pentagon növekvő érdeklődése az antropológia iránt nagy vitát váltott ki az Amerikai Antropológusok Szövetsége (AAA) és a haderő között, hogy a társadalomtudósok pontosan milyen feladatokat láthatnak el a katonaság oldalán. A Védelmi Minisztérium által finanszírozott Human Terrain System, ${ }^{22}$ amely 2007 és 2014 között közvetlenül a müveleti területen alkalmazott szociokulturális szakértőket az idegen társadalom jobb megismerésére, a lehető legellentmondásosabb programnak bizonyult.

A római mitológiában Minerva a bölcsesség és a háború istennője volt, amelyről a program is kapta a nevét. Kezdetben a Minerva kevés médiafigyelmet kapott, azonban az ambiciózus Pentagon-kezdeményezés miatt egyre inkább a figyelem középpontjává vált, főképp azután, hogy összehasonlító cikkek jelentek meg a Camelot-projekt és Minerva feladata kapcsán. Robert Gates, az Egyesült Államok korábbi honvédelmi minisztere 2008. április 14-én bejelentette a Minerva-kezdeményezést az American Universityn tartott konferencián. Mint elmondta: „A Minerva-kezdeményezéssel egyetemi konzorciumot tervezünk, amely elősegíti egyes területek kutatását. Ezek a konzorciumok lehetnek nyílt forrású dokumentumarchívumok tárolói is. A Védelmi Minisztérium - talán más kormányzati ügynökségekkel együttmüködve - finanszírozni

\footnotetext{
Eggers (2014) i. m.

Jorge Montes: A Communist Commentary on Camelot. Chilean Chamber of Deputies, 1965.

22 Sztankai Krisztián: A kulturális antropológia a terror elleni háborúban. Hadtudományi Szemle, 6. (2013), 1. 187-192.
} 
tudná ezeket a projekteket. Hadd mondjam ki egyértelmüen, hogy a Minerva Konzorciumok valamennyi elemének alapelve a teljes nyitottság és az akadémiai szabadság és az integritás szigorú betartása. Ebben a projektben nem lesz hely az »érzékeny, de nem osztályozott « vagy egyéb korlátozásokra."23

A Robert Gates honvédelmi miniszter által megfogalmazott programérvben olyan kutatási témákat szponzorál a DOD, amelyek többek között a terrorizmussal, a vallási radikalizmussal, Kína nemzetközi szerepének és katonai szükségleteinek megértésével foglalkoznak. ${ }^{24}$

A Védelmi Minisztérium és a National Science Foundation (Nemzeti Tudományos Alapítvány) 2008-ban indította el végül a Minerva Initiative programot, amely kezdetben 50 millió dollár támogatást kapott. A projekt honlapja szerint a Minerva célja „a Nemzet legfontosabb egyetemei forrásainak felhasználása és csoportosítása"; "[a]rra törekszik, hogy meghatározza és fejlessze az alapvető ismereteket a jelenlegi és a jövőbeli konfliktusok háttereiről, szem előtt tartva a világ legfontosabb régióinak és politikai folyamatainak jobb megértését". A pályázati felhívás az antropológiát, a közgazdaságtant, a politológiát, a szociológiát, a társadalmi és kognitív pszichológiát és a számítástechnikát említi mint releváns tudományágakat. A finanszírozásban részesülő projektek között szerepel: „Új elemzés a szélsőséges csoportok társadalmi befolyásának és meggyőzésének mérésére és leküzdésére", amelynek felelőse az Arizona State University, „A média mobilizálása: a folyóiratok, zenék és videók mély és összehasonlító elemzése a terrorizmus korában" a Georgia State University közremüködésével, a „Környezeti terjedés nyomon követése a társadalmi fertőzésekben” címmel a Cornell Egyetem kutatása által, „A radikalizálódás/deradikalizáció motivációi és kognitív-társadalmi elemei" a Marylandi Egyetem munkásságában. A Minerva-projektek közül legalább néhány egyértelmüen kapcsolódik a forradalmak/ radikalizálódás elörejelzésének problémájához. Elkerülhetetlenül vannak olyan idegtudományi projektek is, amelyeket a Minerva finanszíroz. Például a Chicagói Egyetem kutatói 3,4 millió dollár támogatást kaptak a „Mártírhalál társadalmi és neurológiai kutatása" projekthez, amely azt vizsgálja, hogy az ISIS propagandavideói hogyan rezonálnak a nézőkkel. Céljuk, hogy pontosan feltárják, mi történik az agyban, amikor az egyént arra ösztönzik, hogy megváltoztassa véleményét. ${ }^{25}$

\section{6. Összefoglalás}

Nagyon sok cikk foglalkozik azzal a kérdéssel, hogy mennyire etikus és szabad a különböző diszciplínákat katonai feladatokba bevonni. Talán a kérdés nem az etikusság vizsgálata, hanem a felhasználás mélysége. „A fegyveres küzdelem, a háború emberi létünk egyik meghatározó jellemzője. Olyan társadalmi létforma, amely kialakulása, illetve bekövetkezése esetén - összetettsége, bonyolultsága, valamint a társadalmi lét minden más területére történő kiterjedése okán - adott történelmi időszakban az érintett, illetve érdekelt társadalmi csoportok szempontjából elsőrangú, minden

U.S. Department of Defense.

John Tirman: Pentagon Priorities and the Minerva Program. 2008.

25 Armin Krishnan: Military Neuroscience and the Coming Age of Neurowarfare. Routledge, 2016. 86. 
más társadalmi tevékenységet maga mögé utasító, helyesebben szólva, azokat maga alá rendelő társadalmi tevékenységgé alakul."26 Mint ilyen, a háború elkerülése létfontosságú, amiben a nemzetbiztonsági szolgálatok szerepe kimagasló. A megválasztott eszközök között, amelyekkel életeket lehet menteni, nem lehet válogatni. Háborús időkben a harceljárások és a technológiai újítások az ellenség egyedi taktikájához való alkalmazkodás eredményei, amelyekben a társadalomtudományok felhasználása elkerülhetetlen.

A háborút ebben a különleges században nem a fegyverek száma, a technikai fölény és a jobban kiképzett katona fogja a nyertes felé billenteni, hanem a hadtudomány gerince, azaz az olyan társadalomtudományok integrációja és alkalmazása, mint a szociológia, pszichológia, antropológia, politológia, a kommunikáció- és médiatudomány képessége, a tömegtájékoztatás, a közgazdaságtan és természetesen a nemzetközi jog. Ezen tudományok felhasználása a katonai múveletekben a tervezéstől a végrehajtásig a modern hadviselés alapjaivá váltak. ${ }^{27}$

\section{Felhasznált irodalom}

Eggers, Keil: Project Camelot: A Legacy of Imperial Geostrategy. 2014. Elérhető: www. galtung-institut.de/en/2014/project-camelot-a-legacy-of-imperial-geostrategy/ (A letöltés dátuma: 2020. 05. 25.)

Gusterson, Hugh: Project Minerva and the Militarization of Anthropology. Questia. Elérhetö: www.questia.com/magazine/1G1-216486929/project-minerva-and-the-militarization-of-anthropology (A letöltés dátuma: 2020. 05. 26.)

Horowitz, Irving Louis: The Rise and Fall of Project Camelot: Studies in the Relationship between Social Science and Practical Politics. Revised edition, The MIT Press, 1967.

Kaló József: A mai világrend kialakulása. A hidegháború és az 1945 utáni helyi háborúk. In Hausner Gábor (szerk.): Honvédelmi alapismeretek. Budapest, Nemzeti Közszolgálati Egyetem, 2019. 67-100.

Krishnan, Armin: Military Neuroscience and the Coming Age of Neurowarfare. Routledge, 2016. DOI: https://doi.org/10.4324/9781315595429

Miser, Hugh J.: Operations Research and Systems Analysis. Science, 209. (1980), 4452. 139-146. DOI: https://doi.org/10.1126/science.209.4452.139

Montes, Jorge: A Communist Commentary on Camelot. Chilean Chamber of Deputies, 1965. Elérhető: www.namebase.net:82/campus/camelot.html (A letöltés dátuma: 2020. 05. 26.)

Project Camelot and Its Aftermath. In Ellen Herman: The Romance of American Psychology. Berkeley, University of California Press, 1995. 153-174. Elérhető: https://publishing.cdlib.org/ucpressebooks/view?docld=ft696nb3n8\&chunk. id=d0e3318\&toc.depth=1\&toc.id=d0e3318\&brand=ucpress (A letöltés dátuma: 2020. 05. 25.)

Szendy István: Hadügy és hadivselés. Budapest, Dialóg Campus, 2017. 9.

27 Sztankai Krisztián: A társadalomtudományok alkalmazásának szükségszerüsége a Magyar Honvédségben. Hadtudományi Szemle, 9. (2018), 1. 253-269. 254. 
Price, David H.: Cold War Anthropology: The CIA, the Pentagon, and the Growth of Dual Use Anthropology. Duke University Press Books, 2016. DOI: https://doi. org/10.1215/9780822374381

Reivich, Lois: The Rise and Fall of Project Camelot. Nacla, 2007. Elérhetö: https://nacla. org/article/rise-and-fall-project-camelot (A letöltés dátuma: 2020. 05. 26.)

Shrader, Charles R.: History of Operations Research in the United States Army, Volume II: 1961-1973. Washington, D. C., 2006.

Solovey, Mark: Project Camelot. In Encyclopedia of Critical Psychology. 2012. Elérhető: http://individual.utoronto.ca/solovey/papers/Solovey_Project_Camelot_Entry_ in_Thomas_Teo_ed_Encyclopedia_of_Critical_Psychology__March_24_2012. pdf (A letöltés dátuma: 2020. 05. 26.)

Szendy István: Hadügy és hadviselés. Budapest, Dialóg Campus,2017.

Sztankai Krisztián: A kulturális antropológia a terror elleni háborúban. Hadtudományi Szemle, 6. (2013), 1. 187-192.

Sztankai Krisztián: A társadalomtudományok alkalmazásának szükségszerüsége a Magyar Honvédségben. Hadtudományi Szemle, 9. (2018), 1. 253-269. DOI: https://doi.org/10.32563/hsz.2019.1.15

Tirman, John: Pentagon Priorities and the Minerva Program. 2008. Elérhető: https:// items.ssrc.org/the-minerva-controversy/pentagon-priorities-and-the-minerva-program/ (A letöltés dátuma: 2020. 05. 25.)

U.S. Department of Defense. Elérhető: https://archive.defense.gov/Speeches/Speech. aspx?SpeechID=1228 (A letöltés dátuma: 2020. 05. 25.)

Who We Are. American University. Elérhetö: www.american.edu/about/history.cfm (A letöltés dátuma: 2020. 05. 25.) 